ECONOMIC THEMES (2019) 57(4): 433-457

\title{
EXPORT COMPETITIVENESS OF THE ECONOMIC SECTORS OF BOSNIA AND HERZEGOVINA
}

\author{
Milenko Krajišnik \\ University of Banja Luka, Faculty of Economics, Bosnia and Herzegovina \\ $\triangle$ milenko.krajisnik@ef.unibl.org
}

Sanja Popović

Msc student at University of Banja Luka, Faculty of Economics, Bosnia and Herzegovina

$\bowtie$ sanja.popovic.jakovljevic@gmail.com

UDC

339.564

(497.6)

Review

paper

Received:

28.08.2019

Accepted:

01.12 .2019

\begin{abstract}
The competitiveness of the national economy, its sectors anc companies is essential for economic growth and development in the condition: of the global market. This importance is especially expressed for small oper economies, such as Bosnia and Herzegovina (B\&H). Bosnia and Herzegovine must strengthen its export position in the most competitive sectors, so that i can develop under conditions of increasingly liberalized world trade, witl growing competition. The aim of this paper is to investigate the sectora structure of $\mathrm{B} \& \mathrm{H}$ exports, the competitiveness, significance and performance of certain sectors, in order to identify weaknesses and possible ways o improvement. For the purposes of this analysis, the Trade Competitivenes: Map analysis methodology was used to assess the competitiveness of the sector, using the Trade Performance Index (TPI). The main aim of the methodology is to determine sectoral export performance, in order to facilitat strategic market research and monitoring of national foreign trad, performance. $\mathrm{B} \& \mathrm{H}$ has the poor export sector structure, with the low level o international competitiveness, reflected in the large share of resource intensive products and low-value processing products with low added value Improving competitiveness could be achieved by strengthening the mos competitive sectors, as well as by changing the economic structure toward: the development of technologically intensive and highly profitable sectors o the economy.
\end{abstract}

Keywords: competitiveness, export, Trade Performance Index, economic sectors, Bosnia and Herzegovina

JEL classification: E60, F14 


\section{Introduction}

The globalization process, as one of the basic characteristics of modern society, in the economic sense, increasingly brings complex process of internationalization, liberalization, cross-border trade, investment, capital flows, technology transfer, labor mobility and rising competition. It has increased the interest of policy makers and economic analysts for the international competitiveness of enterprises, industry, sectors and national economies. The international competitiveness issue has recently gained increasing attention due to its connection to prosperity. The positive relationship between the country's international competitiveness and its economic prosperity has become evident.

Competitiveness can be analysed at the level of: enterprises, sectors / industries, countries, regions. While the competitiveness of the company has been the subject of interest from the beginning of competitiveness concept, since the end of the seventies of the 20th century, the term competitiveness is increasingly used in relation to the performance of industry or national economies. The export performance and international competitiveness of the manufacturing industry and its sectors has become the main concern of decision makers around the world, with increasing attention given to its role in boosting economic growth and development (Tassey, 2001).

For Bosnia and Herzegovina (B\&H), as the small open economy and the country in transition, international export competitiveness of its enterprises, economic sectors and the economy as a whole, is of the paramount importance. In order to survive in the increasingly liberalized conditions of world trade, with increasing competition, $\mathrm{B} \& \mathrm{H}$ have to strengthen its export position in the most competitive sectors. Due to the numerous positive effects that the export has on the economy, it is very important for economic policy makers to create appropriate economic policies that will favor the improvement of the competitiveness of B\&H's export sectors, and thus improve the foreign trade balance and the economy as a whole.

The importance of the export competitiveness of the sector stems from the fact that B\&H's long-term goals are oriented towards joining the European Union, especially now when the entry of Bosnia and Herzegovina into the World Trade Organization is more certain. B\&H should work intensively on the improvment of its international competitiveness, in order to deal with growing competition more easily, as well as on the adaptation of the economic structure to world demand by strengthening its most competitive sectors.

Therefore, the main task of the paper is to analyze the sectoral structure of $\mathrm{B} \& \mathrm{H}$ exports, the performance and significance of each sector in $\mathrm{B} \& \mathrm{H}$ total exports, in order to identify weaknesses and determine the possible directions of improvement. The aim of the research is to gain the new insights on the state and 
position of export competitiveness of the $\mathrm{B} \& \mathrm{H}$ sectors, to point out the importance of the export competitiveness of those sectors, in order to identify the key export sectors on which the export orientation should be based.

The analysis of the sectoral export competitiveness, in order to formulate strategies, both foreign-trade companies and strategies and policies defined by governments, is not an easy task. In order for the research results to provide good guidance, it is necessary to provide an answer to the research problem which is: "What is the sectoral structure of B\&H export, which sectors are "winners" and which sectors are "losers" in foreign trade based on the foreign trade performance indicators?". The main research hypothesis based on the research problem, is: Sectors of Bosnia and Herzegovina have the low level of international trade competitiveness. The auxiliary hypothesis of the research is: The low level of export competitiveness of the economic sectors is reflected in the poor sectoral structure dominated by sectors with resource-intensive and labor-intensive products, sectors with products of low processing stage and low value added.

The foreign trade deficit is one of the key economic problems of $\mathrm{B} \& \mathrm{H}$. B\&H is the small open economy, with the small share in the world trade. This implies that it is crucial to identify the $\mathrm{B} \& \mathrm{H}$ sectors which achieve the best export results, in order to strengthen its foreign trade position. In recent years, modest improvement of competitiveness and foreign trade position of $\mathrm{B} \& \mathrm{H}$ have been achieved. However, the improvement of competitiveness should not happen haphazardly. It is necessary to develop and direct this process, so that the effects would be as good as possible. It is necessary to find the model that will solve the problem of poor competitiveness of certain economic sectors, build export orientation on the most competitive sectors, thus improving the foreign trade balance and economic structure of $\mathrm{B} \& \mathrm{H}$.

\section{The concept of international competitiveness of economic sectors}

The term "competitiveness" is one of the most commonly used concepts in the economy, although there is no generally accepted definition of it.

Nobel laureate in economics Paul Krugman believes that if competitiveness has any meaning, it is just another way to express productivity, emphasizing that the ability of a country to improve its living standard depends almost entirely on its ability to increase its productivity. According to Krugman, competitiveness is the meaningless word when applied to the national economy level (Krugman, 1990). This is an extreme attitude, because the government, through its policies, significantly affects the conditions in which enterprises create and improve their competitiveness. Michael Porter, who is one of the conceptual creators of the notion of competitiveness, in the form in which it is known today, in his work "Competitive advantage of nations", states that the competitiveness of the national 
economy (macro competitiveness) arises precisely from the competitiveness of companies belonging to that economy. According to Porter, competitiveness can be observed only at the enterprise level.

Despite these views, the idea that the economic success of national economy depends on its international competitiveness emerged among business, political and intellectual circles in the late seventies (Krugman, 1996). At that time, the World Economic Forum had started with publishing the Global Competitiveness Report, which included the ranking list of national economies by competitiveness.

The most important international organizations gave their definitions of the concept of competitiveness. The Organization for Economic Co-operation and Development (OECD) defines competitiveness as the measure of the country's ability to produce goods and services that pass international market test in free and equal market conditions (OECD, 2001). International Institute for Management Development defines competitiveness as "the ability of the national economy to produce the new value and increase national wealth" (Bjelic, 2008). The concept of competitiveness according to the European Commission is defined as the ability of a country to provide its population with a high and rising standard of living with high employment rates on the sustainable basis (European Commission, 2001). The World Economic Forum and one of the most famous associates of this institution, Michael Porter, defines competitiveness as the set of institutions, policies and factors that determine the level of the country productivity. The level of productivity, on the other hand, defines the sustainable level of prosperity which the economy can achieve. If the economy is more competitive, it will be able to produce the higher level of income for its citizens (Schwab \& Porter, 2008). According to Kovacevic, investment rates, trade account and external debt should be added to the competitiveness definition of the World Economic Forum (Kovacevic, 2010).

Bearing in mind the aforementioned definitions of competitiveness, it is clear that competitiveness is the complex concept wich has no unique harmonized definition. On the contrary, most economic experts agree that the XXI century is the period of global economic competition due to the globalization process. In contemporary conditions, competitiveness is the integral part of development management, in order to more effectively create social wealth and long-term sustainable growth.

In general, competitiveness can be defined as the concept that arises from the ability of business entities, individual industrial sectors or the national economies to market products and services more successfully than some other business entities, industrial sectors or national economies. Competitiveness is the key concept in the modern economy, since the competitiveness of the economy also results in the higher standard of living for citizens. The primary goal of achieving and improving competitiveness in contemporary conditions is permanent and 
sustainable economic growth expressed through GDP growth and GDP per capita growth, which ensures the increase in employment and, ultimately, the rise in the citizens' quality of life.

The competitiveness was originally thought to be measurable only at lower levels, most often for businesses, when competitiveness denotes the ability to create, produce, sell and service products or services (Kovacevic, 2010). Lately, the competitiveness problem is analyzed at various levels of socio-economic organization, from the level of products, enterprises, sectors, branches to the competitiveness of national economies and regional integration. Multidimensional approach to the concept of international competitiveness, both enterprises (international microeconomics) and individual sectors (international mesoconference), as well as the economy as a whole (international macroeconomics), is increasingly present.

Macro competitiveness was neglected until the second half of the 20th century in relation to the concept of microcompetitiveness. However, since then, macro competitiveness has gained its importance, not only as an economic, but also as a political issue. Assessing country's competitiveness and developing policies for its advancement have become officially institutionalized tasks in many national economies: the United States, the United Kingdom, Belgium, Italy, the Netherlands and Japan. The increasing practical use of the concept of competitiveness in assessing the success of national economies in coping with economic challenges corresponds to the pioneering efforts of the United States and the European Union in the early 1990s, which formed the councils for improving competitiveness (Kitson et al. 2004).

Macro competitiveness refers to the competitiveness of national economies compared to other national economies, while the concept of micro competitiveness refers to the business of enterprises of one national economy in relation to business of foreign companies (Bjelic, 2008). Given the fact that the concept of international competitiveness, as relative concept, implies some international comparisons, international sector competitiveness can be defined as consideration of the sector competitiveness of one national economy compared to the sector competitiveness of other national economies.

The concept of macro competitiveness and methods of measuring, Krugman defined as "dangerous obsessions" (Krugman, 1994) and as the longstanding mistake that made international trade a new and exaggerated rhetoric (Krugman, 1996). Krugman defined the concept of competitiveness as the ability to keep foreign trade in balance, while achieving the adequate standard of living (Kovacevic, 2010). According to Krugman, when looking at enterprise-level competitiveness, the success of one enterprise usually means the loss for all others (known as zero-sum games), while in the observation of competitiveness between countries, especially in the long term, this is usually not the case (Vukovic, 2013). 
One definition of macro competitiveness defines this term as the ability of a region or a country to create added value and jobs and to improve the living standards, and the ability of a country (region) to reach GDP above target (Ajginger et al., 2013). Porter defines macro competitiveness as the ability of a country to achieve high-current productivity (Porter, 1998). In the short term, the time gap between the changes in productivity indicators and changes in the country's competitive position in the world can be created. On the other hand, in the long term, productivity in the use of resources is one of the basic determinants of the competitiveness of the national economy. Changes in competitiveness in the short term could occur without changes in productivity, and Tomas cites devaluation as one of such determinants of competitiveness (Tomas, 2011).

Difficulties in theoretical coverage of the concept of competitiveness are related to the fact that competitiveness is based on relative positions; it has different meanings at different levels of aggregation and the dynamics of the observed economic system plays an important role in determining the phenomenon of competitiveness (Cvetanovic et al., 2012). There is no generally accepted definition in the professional literature for the sector competitiveness. Sector-level competitiveness is often viewed as a result of the strategies and procedures of companies operating in the sector. ${ }^{1}$ In the case of sectoral competitiveness, the macroeconomic assessment at the sectoral level is carried out, so there is an overlap of macro and meso levels of competitiveness. The foreign trade balance serves as the basis for clarifying and analyzing the comparative advantages of the industry / sector. According to Fleyerski, competitiveness is the capacity of the sector, industry or branch to produce and sell their goods at the price, quality and other characteristics that are more attractive than the comparative characteristics of goods offered by competitors (Fleyerski, 1984). Cho and Moon point out that, when defining competitiveness at the national economy level, it is necessary to focus not on the economy as a whole, but on its sectors / industry (Cho \& Moon, 2000). The competitiveness of the economic sectors has dominant influence on the overall competitiveness of the national economy and it is the basis of export competitiveness. Export competitiveness is affected by the large number of factors (productivity, production costs, technological development, etc.), but it is predominantly determined by the level of sectoral competitiveness.

\section{Methods of measuring international sectoral competitiveness}

In the $21^{\text {st }}$ century, the international competitiveness is becoming an actual subject of analysis. In addition to the absence of the generally accepted definition of competitiveness, more approaches to measuring competitiveness have been

${ }^{1}$ The terms sector and industry, in defining the notion of competitiveness, are regarded as terms with the same meaning. 
developed. The concept of competitiveness is very broad. It includes the set of qualitative and quantitative factors that need to be quantified through certain indicators, in order to allow comparability of competitiveness between different national economies.

Each approach of measuring competitiveness emphasizes certain factors which determine competitiveness. The development of different competitiveness measuring methods follow the evolution of the concept of competitiveness, where competitiveness was initially linked to the export capacity of a country exclusively, which later included much larger number of parameters determining competitiveness and led to the creation of index parameters for competitiveness assessment (Tesic, 2013).

Some international organizations dealing with competitiveness have defined indigenous methods for assessing international competitiveness, among which the best known are:

- at the level of national economies:

- Global competitiveness index - GCI of World Economic Forum and

- The World Competitiveness Yearbook of International Institute for Management Development;

- at the enterprise level:

- Business competitiveness index - BCI of World Economic Forum.

As indicators for measuring the competitiveness of some specific industry / sector, relative prices are used in relation to key competitors, i.e. national competitiveness price in a particular sector. In addition, other indicators are also used:

- Revealed Comparative Advantage - RCA, developed by Bela Balassa, which measures the participation of a particular product (sector) in total country exports in relation to the share of the same product (sector) in total world exports, and shows the country's export specialization.

- Method of constant market share and

- Analysis of the trade competitiveness by the International Trade Center.

For the purposes of analyzing the competitiveness of a national economy in exports, the International Trade Center (ITC) ${ }^{2}$ has developed the Trade Competitiveness Map. The main goal of this methodology is to determine sectoral export performance, in order to facilitate strategic market research and monitoring national (external) trade performance. Analysis of the (external) trade competitiveness of the International Trade Center includes:

\footnotetext{
${ }^{2}$ The International Trade Center is the joint agency of the World Trade Organization (WTO) and the United Nations Trade and Development Organization (UNCTAD), which was established with the aim to provide support to the export improvement of developing countries and countries in transition, especially their small enterprises.
} 
(1) Evaluation of Trade Performance Index (TPI),

(2) Evaluation of National Export Performance and Determination of National Export Profile (NEP). Basic function of NEP is to evaluate the export performance of specific national economy from the aspect of: (a) product export, (b) the global demand dynamics, and (c growth trends inleading export products.

Given that the Trade Performance Index in this paper is used for the analysis of export competitiveness of the sector of Bosnia and Herzegovina, the structure of the mentioned index is explained in more detail below.

The development of the Trade Performance Index (TPI) is based on the Standard International Trade Classification (SITC, Revision 3) ${ }^{3}$. The index is calculated for more than 180 countries and 14 sectors. The TPI, as the composite index, consists of 22 quantitative indicators. The indicators included in the TPI are divided into three categories, as shown in Table 1. For each country and each export sector, the TPI index provides indicators on the overall country profile, the current foreign trade position of the national economy and the decomposition of changes in the world market share of the sectors for the observed national economy.

The classification of indicators, which are part of the TPI index, indicates that those from the first group are used only for, the so-called, descriptive descriptions. The remaining two groups of indicators, i.e. current performance indicators and indicators of change in world market share, according to export performance, are used for calculating two aggregate ranks and determining the current and the change index. The first composite index, the current index, represents a static component, determines the current position of the national economy sector and is based on a simple average of the rank based on the indicators (P1), (P2), (P3), (P4) and (P5). The second, the change index, representing the dynamic component of determining export performance, shows the evolution of export performance and is based on indicators from the third group.

\footnotetext{
3 Standard International Trade Classification (SITC, Revision 3) is the United Nations Basic Classification of Goods for Foreign Trade Statistics, based on the Harmonized System of the World Customs Organization. Based on this classification, the products are grouped into 14 export sectors for the needs of the International Trade Center analysis, according to the similarity of the product.
} 
Table 1: Trade Performance Index indicators divided into three groups ${ }^{4}$

\begin{tabular}{|l|l|l|}
\hline GENERAL EXPORT & $\begin{array}{l}\text { CURRENT PERFORMANCE } \\
\text { INDICATORS } \\
\text { (position in the last observed } \\
\text { year) }\end{array}$ & $\begin{array}{l}\text { DECOMPOSITION OF } \\
\text { CHANGES IN WORLD } \\
\text { MARKET SHARE } \\
\text { (explaining the changes } \\
\text { in the world market } \\
\text { share for the period of } \\
\text { five years) }\end{array}$ \\
\hline G1 - Value of exports & P1 - Value of net exports & C1a - Competitive effect \\
\hline $\begin{array}{l}\text { G2 - Export growth rate } \\
\text { (in \%) }\end{array}$ & P2 - Per capita exports & $\begin{array}{l}\text { C1b - Initial geographic } \\
\text { specialization }\end{array}$ \\
\hline $\begin{array}{l}\text { G3 - Share in national } \\
\text { exports (in \%) }\end{array}$ & $\begin{array}{l}\text { P3 - Export share in world } \\
\text { market (in \%) }\end{array}$ & $\begin{array}{l}\text { C1c - Initial production } \\
\text { specialization }\end{array}$ \\
\hline $\begin{array}{l}\text { G4 - Share in national } \\
\text { imports (in \%) }\end{array}$ & P4a - Product diversification & C1d - Adjustment effect \\
\hline $\begin{array}{l}\text { G5 - Relative trade balance } \\
\text { (in \%) }\end{array}$ & $\begin{array}{l}\text { P4b - Product concentration } \\
\text { (in relation to other national } \\
\text { economies) }\end{array}$ & $\begin{array}{l}\text { C2 - Adjusting to the } \\
\text { dynamics of world } \\
\text { demand }\end{array}$ \\
\hline $\begin{array}{l}\text { G6 - Relative unit value } \\
\text { P5a - Market diversification }\end{array}$ & $\begin{array}{l}\text { Changes in production } \\
\text { concentration }\end{array}$ \\
\hline $\begin{array}{l}\text { Average annual change in } \\
\text { relative unit value over the } \\
\text { last available five-year } \\
\text { period }\end{array}$ & $\begin{array}{l}\text { P5b - Market concentration (in } \\
\text { relation to other national } \\
\text { economies) }\end{array}$ & $\begin{array}{l}\text { Changes in market } \\
\text { concentration }\end{array}$ \\
\hline $\begin{array}{l}\text { Revealed comparative } \\
\text { advantage }\end{array}$ & \multicolumn{2}{|l}{} \\
\hline
\end{tabular}

Source: International Trade Centre. (2014). Trade Competitiveness Map - Benchmarking national and sectoral trade performance - Trade Performance Index - Technical notes. ITC's Market Analysis and Research.p.5.

\section{Overview of the foreign trade position and global competitiveness of $\mathrm{B} \& \mathrm{H}$}

Foreign trade is significant for all national economies, especially for small economies, such as Bosnia and Herzegovina. Before analyzing the Trade Performance Index for the sectors of Bosnia and Herzegovina in more detail, which

\footnotetext{
${ }^{4}$ In this paper, the methodology for making this index and all individual indicators that are included in the index will not be presented. For details on the methodology of calculating the index, the method and sources of data collection, grouping products into 14 sectors, the indicators on which the index is based, the variables used in its calculation, and for other information, refer to the instructions of the International Trade Center: http: // www.intracen.org/.
} 
separately analyzes the export side of the external trade, it is necessary to analyze the general indicators of $\mathrm{B} \& \mathrm{H}$ foreign trade.

Table 2: Value of exports, imports, foreign trade balance and scope of foreign trade of B\&H in the period 2007-2017 (in millions of BAM)

\begin{tabular}{|lrrrrr|r|}
\hline Year & Export & Import & $\begin{array}{l}\text { Foreign } \\
\text { balance } \\
(3)=(1)-(2)\end{array}$ & $\begin{array}{l}\text { trade } \\
\text { foreign trade } \\
(4)=(1)+(2)\end{array}$ & $\begin{array}{l}\text { The volume of } \\
\text { Import coverage by } \\
\text { exports, in \% } \%(1) /(2) * 100\end{array}$ \\
\hline 2007 & 5,937 & 13,898 & $-7,962$ & 19,835 & $42.7 \%$ \\
\hline 2008 & 6,712 & 16,293 & $-9,581$ & 23,005 & $41.2 \%$ \\
\hline 2009 & 5,530 & 12,348 & $-6,818$ & 17,878 & $54.8 \%$ \\
\hline 2010 & 7,096 & 13,616 & $-6,521$ & 20,712 & $53.0 \%$ \\
\hline 2011 & 8,222 & 15,525 & $-7,303$ & 23,747 & $51.5 \%$ \\
\hline 2012 & 7,858 & 15,253 & $-7,395$ & 23,111 & $53.2 \%$ \\
\hline 2013 & 8,380 & 15,170 & $-6,790$ & 23,550 & $57.9 \%$ \\
\hline 2014 & 8,682 & 16,199 & $-7,518$ & 24,881 & $58.3 \%$ \\
\hline 2015 & 8,987 & 15,852 & $-6,864$ & 24,839 & $60.9 \%$ \\
\hline 2016 & 9,417 & 16,140 & $-6,722$ & 25,557 & 29,188 \\
\hline 2017 & 11,054 & 18,134 & $-7,080$ & 29 & \\
\hline
\end{tabular}

Source: Agency for statistics of B\&H, retrieved from: http://www.bhas.ba/, accessed 10.03.2019.

The foreign trade data for $\mathrm{B} \& \mathrm{H}$ shown in Table 2 indicates several characteristics and tendencies of foreign trade in the analyzed 10 year period:

- The value of imports and exports, i.e. the volume of foreign trade exchange is on the rise. The significant decline in import and export was recorded in 2009, when the effects of the global economic crisis of 2008 "Great recessions" also spread to $\mathrm{B} \& \mathrm{H}$.

- The value of imports is higher than the value of exports in the observed period, which shows that the foreign trade balance of Bosnia and Herzegovina is in deficit;

- The foreign trade deficit is the long-standing problem of $\mathrm{B} \& \mathrm{H}$;

- The rate of imports coverage by exports recorded the positive trend. While the coverage ratio of export by imports in 2007 was only 42.7\%, in 2017 this rate was $60.9 \%$, indicating the significant improvement in this indicator.

Given the fact that the competitiveness observed at the level of the national economy depends, to the large extent, on competitiveness at the level of its economic sectors and enterprises, before the detailed analysis of sector competitiveness, the rank of $\mathrm{B} \& \mathrm{H}$, according to the generally accepted global competitiveness indicator - Global Competitiveness Index of the World Economic Forum, is given in the table below. 


\section{Graph 1: Foreign trade deficit of B\&H, in millions of BAM,} for the period from 2007 to 2017.

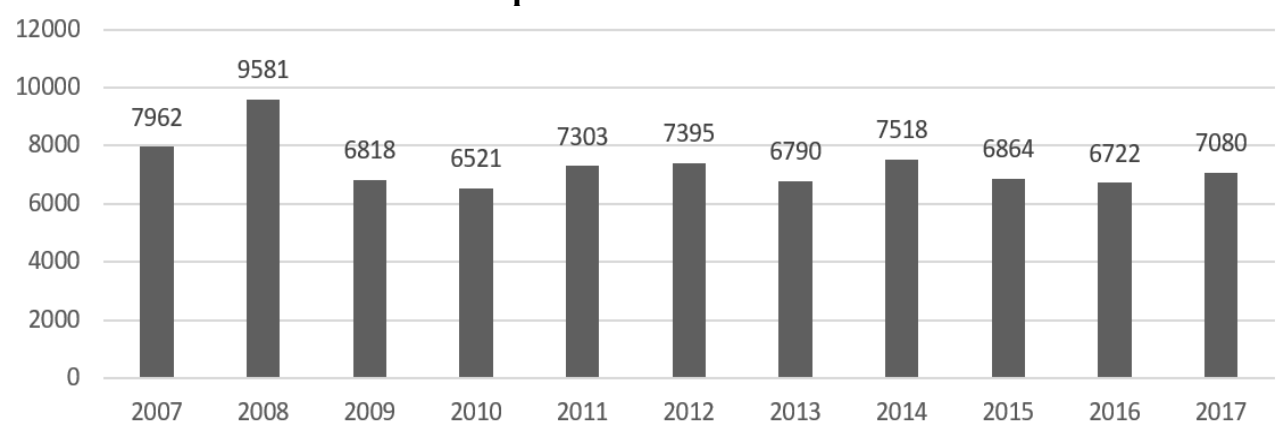

Source: Agency for statistics of B\&H, retrieved from: http://www.bhas.ba/, accessed 10.03.2019. Author's graphic view.

The ranking of Bosnia and Herzegovina based on the Global Competitiveness Index is the worst in relation to all the countries in the region. The rank of B\&H worsened in 2015, after a five-year improvement. In 2016, B\&H was ranked $107^{\text {th }}$. The slight improvement was achieved in 2017, when B\&H, according to Global Competitiveness Index, was on the $103^{\text {rd }}$ position.

Table 3: Ranks of B\&H and neighboring countries according to the Global Competitiveness Index

\begin{tabular}{|c|c|c|c|c|c|c|c|c|}
\hline Year & $\begin{array}{l}\text { Total number } \\
\text { of countries }\end{array}$ & Albania & $\bar{B} \& \mathrm{H}$ & Montenegro & Croatia & Macedonia & Slovenia & Serbia \\
\hline 2006 & 125 & 98 & 89 & 87 & 51 & 80 & 33 & 87 \\
\hline 2007 & 131 & 109 & 106 & - & 57 & 94 & 39 & - \\
\hline 2008 & 134 & 108 & 107 & 65 & 61 & 89 & 42 & 85 \\
\hline 2009 & 133 & 96 & 109 & 62 & 72 & 84 & 37 & 93 \\
\hline 2010 & 139 & 88 & 102 & 49 & 77 & 79 & 45 & 96 \\
\hline 2011 & 142 & 78 & 100 & 60 & 76 & 79 & 57 & 95 \\
\hline 2012 & 144 & 89 & 88 & 72 & 81 & 80 & 56 & 95 \\
\hline 2013 & 148 & 95 & 87 & 67 & 75 & 73 & 62 & 101 \\
\hline 2014 & 144 & 97 & - & 67 & 77 & 63 & 70 & 94 \\
\hline 2015 & 140 & 93 & 111 & 70 & 77 & 60 & 59 & 94 \\
\hline 2016 & 138 & 80 & 107 & 82 & 74 & 68 & 56 & 90 \\
\hline 2017 & 137 & 75 & 103 & 77 & 74 & - & 48 & 78 \\
\hline
\end{tabular}

Source: World Economic Forum. (2018), retrieved from: https://www.weforum.org/reports/the-global-competitveness-report, accessed: 01.03.2019.

Bosnia and Herzegovina records poor foreign trade performance, which is primarily reflected in the long-term foreign trade deficit and the low ranking, according to the Global Competitiveness Index. All of the above indicates that 
there is the need to improve $\mathrm{B} \& \mathrm{H}$ foreign trade position and competitiveness, in particular to facilitate export, considering multiplicative effects of export on the whole economy. In this regard, the export competitiveness of the B\&H sector was analyzed, in order to reveal the structural problems of the B\&H export.

\section{Export competitiveness analysis of economic sectors of Bosnia and Herzegovina based on the Trade Performance Index}

\subsection{Analysis of selected Trade Performance Index indicators}

Although there is an agreement that the foreign trade deficit is one of the key economic problems of $\mathrm{B} \& \mathrm{H}$, there is no enough attention paid to the structural problems of the $\mathrm{B} \& \mathrm{H}$ economy and, consequently, the structure of exports. It is necessary to identify the sectors in which $\mathrm{B} \& \mathrm{H}$ is competitive, and, based on them, build international macro competitiveness, increase exports, and thus improve the foreign trade balance.

The export competitiveness of 14 export, manufacturing $\mathrm{B} \& \mathrm{H}$ sectors ${ }^{5}$ was analyzed on the basis of the Trade Performance Index (TPI), according to the International Trade Center (ITC) methodology. Due to the numerous advantages provided by the $\mathrm{ITC}^{6}$ methodology itself, for analyzing and evaluating the export performance of the B\&H sectors, the TPI index was selected as the most suitable indicator. The aim of this research approach is related to the efforts to achieve more reliable and more realistic assessment of the competitiveness of the B\&H sectors, in order to formulate the best recommendations for their improvement. The assessment of sectoral competitiveness can be used both in the creation of long-term strategic documents regarding the economic development of $\mathrm{B} \& \mathrm{H}$, as well as for specific programs and measures to support exports and improve competitiveness.

The selected indicators, used for calculating the TPI for 14 sectors of $\mathrm{B} \& \mathrm{H}$, are analyzed, as well as the movement of current TPI for B\&H. The analysis covers the period from 2012 to 2016, based on published indicators by ITC.

\footnotetext{
${ }^{5}$ The sectors are defined according to the methodology of the International Trade Center. For the list of products that are part of each individual sector, see: ITC's Market Analysis and Research - TPI Technical Notes, p. 48.

${ }^{6}$ The International Trade Center is the significant international organization that collects, analyzes and publishes foreign trade indicators of almost every country in the world. Analyzing over 180 countries, it covers more than $95 \%$ of world trade and more than 5,000 different products classified to the six-digit level, according to HS methodology (Harmonized System for Marking, HS). The uniform methodology provides the possibility of direct comparisons between countries and sectors. The Trade Performance Index analyzes the complex and multidimensional nature of foreign trade.
} 
Table 4: Overview of selected indicators of TPI Index for 2016

\begin{tabular}{|c|c|c|c|c|c|c|c|}
\hline \multirow[t]{2}{*}{ Sector } & \multirow{2}{*}{$\begin{array}{l}\text { Annual } \\
\text { growth } \\
\text { rate of } \\
\text { export } \\
\text { value } \\
\text { (in } \%)\end{array}$} & \multirow{2}{*}{$\begin{array}{l}\text { Sector } \\
\text { export } \\
\text { share in } \\
\text { total } \\
\text { B\&H } \\
\text { exports } \\
\text { (in \%) }\end{array}$} & \multirow{2}{*}{$\begin{array}{l}\text { Net } \\
\text { exports } \\
\text { of the } \\
\text { sector } \\
\text { ('000 } \\
\text { USD) }\end{array}$} & \multirow{2}{*}{$\begin{array}{l}\text { Relativ } \\
\text { e trade } \\
\text { balance } \\
\text { (in \%) }\end{array}$} & \multicolumn{2}{|c|}{$\begin{array}{c}\text { Share in world } \\
\text { export }\end{array}$} & \multirow{2}{*}{$\begin{array}{l}\text { Relative } \\
\text { change } \\
\text { in world } \\
\text { market } \\
\text { share }\end{array}$} \\
\hline & & & & & $\begin{array}{l}\text { (in } \\
\%)\end{array}$ & $\begin{array}{l}\text { Rank } \\
\text { (No. of } \\
\text { countries } \\
\text { ranked) }\end{array}$ & \\
\hline Fresh food & $8 \%$ & $3 \%$ & $-457,969$ & $-54 \%$ & $0.03 \%$ & $123(177)$ & $9.92 \%$ \\
\hline $\begin{array}{l}\text { Processed } \\
\text { food }\end{array}$ & $3 \%$ & $7 \%$ & $-695,325$ & $-48 \%$ & $0.05 \%$ & 92 (169) & $3.71 \%$ \\
\hline $\begin{array}{l}\text { Wood, wood } \\
\text { products and } \\
\text { paper }\end{array}$ & $3 \%$ & $9 \%$ & 175,793 & $20 \%$ & $0.16 \%$ & 55 (148) & $3.22 \%$ \\
\hline Textiles & $8 \%$ & $1 \%$ & $-353,809$ & $-71 \%$ & $0.02 \%$ & $81(131)$ & $8.22 \%$ \\
\hline Chemicals & $7 \%$ & $7 \%$ & $-911,033$ & $-52 \%$ & $0.02 \%$ & $81(157)$ & $8.59 \%$ \\
\hline $\begin{array}{l}\text { Leather } \\
\text { products }\end{array}$ & $3 \%$ & $7 \%$ & $-1,751$ & $0 \%$ & $0.19 \%$ & $40(127)$ & $0.55 \%$ \\
\hline $\begin{array}{l}\text { Metals and } \\
\text { other basic } \\
\text { manufactures }\end{array}$ & $-6 \%$ & $15 \%$ & $-265,382$ & $-13 \%$ & $0.07 \%$ & $69(152)$ & $-1.51 \%$ \\
\hline $\begin{array}{l}\text { Non- } \\
\text { electronic } \\
\text { machinery }\end{array}$ & $1 \%$ & $6 \%$ & $-284,401$ & $-27 \%$ & $0.03 \%$ & $60(150)$ & $3.07 \%$ \\
\hline $\begin{array}{l}\text { IT \& } \\
\text { Consumer } \\
\text { electronics }\end{array}$ & $3 \%$ & $0 \%$ & $-246,394$ & $-93 \%$ & $0.00 \%$ & $92(121)$ & $3.67 \%$ \\
\hline $\begin{array}{l}\text { Electronic } \\
\text { components }\end{array}$ & $7 \%$ & $3 \%$ & $-162,857$ & $-29 \%$ & $0.01 \%$ & $70(134)$ & $5.55 \%$ \\
\hline $\begin{array}{l}\text { Transport } \\
\text { equipment }\end{array}$ & $8 \%$ & $3 \%$ & $-464,033$ & $-56 \%$ & $0.01 \%$ & $74(150)$ & $6.73 \%$ \\
\hline Clothing & $7 \%$ & $4 \%$ & 1,165 & $0 \%$ & $0.05 \%$ & $73(127)$ & $4.66 \%$ \\
\hline $\begin{array}{l}\text { Miscellaneous } \\
\text { manufacturing }\end{array}$ & $5 \%$ & $15 \%$ & 285,684 & $20 \%$ & $0.06 \%$ & $59(160)$ & $4.98 \%$ \\
\hline $\begin{array}{l}\text { Minerals, } \\
\text { fuels and oils }\end{array}$ & $-9 \%$ & $10 \%$ & $-617,328$ & $-36 \%$ & $0.03 \%$ & $103(165)$ & $7.22 \%$ \\
\hline
\end{tabular}

Source: International Trade Centre. (2019), retrieved from:

http://www.intracen.org/itc/market-info-tools/trade-statistics/, accessed: 20.02.2019.

The value of export in this analysis shows the relative export potential of the sectors of Bosnia and Herzegovina. The value of exports, as static indicator, shows the total value of exports of each sector in the selected year. The higher value of exports indicates the greater importance of the observed sector in the total export of the observed country, i.e. it shows the ability of one sector to take the important position on the foreign market. Given the fact that this is the static indicator, in 
order to gain insight into the dynamics of the value of exports in the analyzed period, the value of sector export by years, in the period from 2012 to 2016, is graphically illustrated, with shown values for 2016. This indicator can be used to compare the export potential of each observed sector of $\mathrm{B} \& \mathrm{H}$ in relation to the same sectors of other countries. Given that the subject of the analysis in this paper is the determination of the sector of "winners" and "losers" among the sectors of Bosnia and Herzegovina, based on their foreign trade performance, the value of exports is used to determine the relative export potential among the $\mathrm{B} \& \mathrm{H}$ sectors.

\section{Graph 2: Value of exports by sectors for the period 2012-2016, in '000 USD}

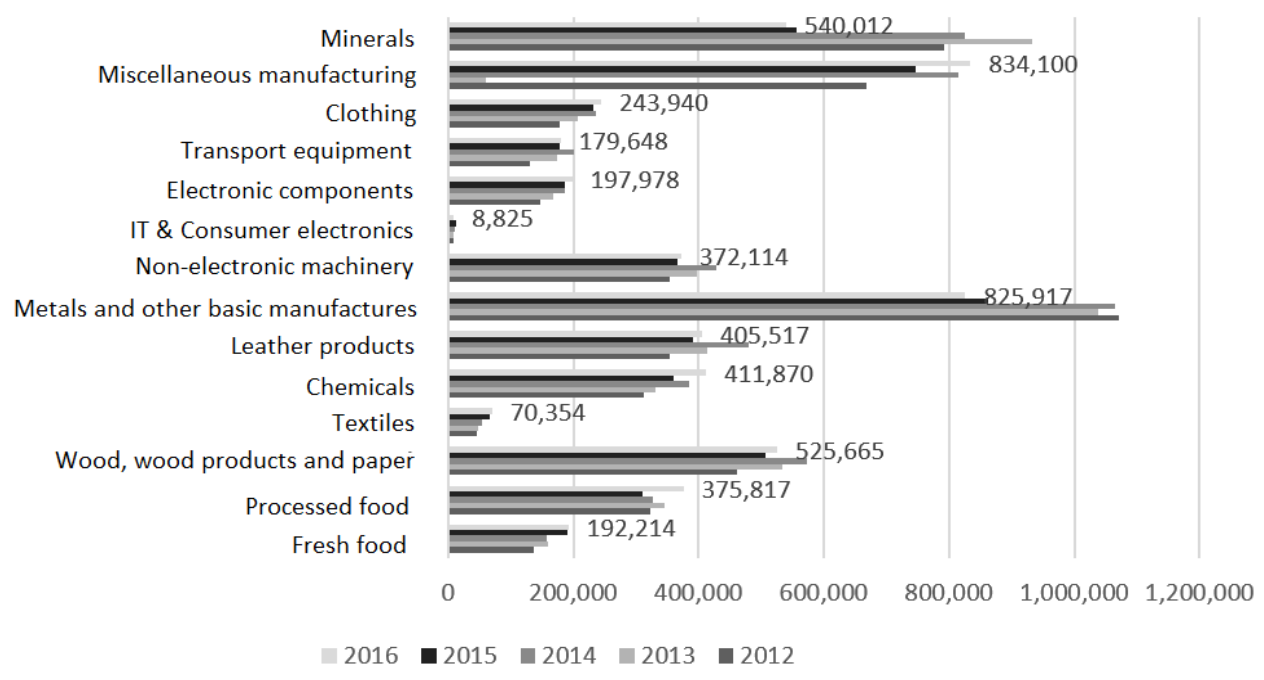

Source: International Trade Centre. (2019), retrieved from:

http://www.intracen.org/itc/market-info-tools/trade-statistics/, accessed: 20.02.2019.

Author's graphic view.

Graph 2 illustrates the relative importance of sectors in the B\&H export basket through identifying the sector whose total value of exports is higher, compared to other sectors of the $\mathrm{B} \& \mathrm{H}$ manufacturing industry. Metal and other primary products, Mineral, fuels and oils and Wood, wood products and paper sectors recorded the highest value of exports throughout the observed period. The sectors with the lowest export of B\&H are IT, telecommunication products and electronic devices, Wool, fabrics and textiles and the Electronic Components sector.

The growth rate of export value for that period indicates the development of exports of the observed sectors over the period of five years. Thus, in the analysis of the growth rate of the $\mathrm{B} \& \mathrm{H}$ sectoral exports value, the exports value in 2016 compared to 2012 is observed. The growth rate of export value for the observed period is obtained by putting into the ratio the value of export of the sector in the last observed year (i.e. the value of sector export in 2016) and the value of sector exports 
in the first year of the observed five-year period (i.e. the value of sector export in 2012). The positive value of this indicator shows that the exports value increased in the observed period, while the negative value shows that the value of exports in 2016 decreased, compared to 2012.

Data for the B\&H sectors show that the largest annual growth rate of exports was recorded in the Fresh Food and Raw Agricultural Products, Wool Textiles and Textile, and Transport equipment sectors ( $8 \%$ each), while some sectors registered the decrease in the value of exports in the observed period: Minerals, fuels and oils (drop of 9\%) and Metal and other primary products (decline of 6\%).

Table 4 shows data on the share of sectoral exports in total national exports of $\mathrm{B} \& \mathrm{H}$ in 2016. The indicator of the share of sector exports in the national exports is the percentage ratio between total sector exports and total exports of the overall national economy. The higher the value of this indicator, the greater the importance of the observed sector in the country's export portfolio.

In the total national exports of Bosnia and Herzegovina, the most involved sectors are: Metal and other primary products, Minerals and fuels and Wood and wood products. The sectors that have the lowest share in the total exports of B\&H are IT, telecommunication products and electronic devices, Electronic Components and Wool, fabrics and textiles. Most sectors have the relatively stable share in total exports of Bosnia and Herzegovina in the period from 2012 to 2016, which could be the indicator of specialization in certain areas.

The value of net exports is the foreign trade balance for a given sector. The positive value shows that the country exports more than it imports (it has the foreign trade surplus). Instead, the foreign trade deficit occurs when the country imports more than it exports. The value of this indicator is obtained when the value of total sector exports is reduced by the value of total imports of that sector. Most of the $\mathrm{B} \& \mathrm{H}$ sectors realized improvements in the value of net exports, i.e. foreign trade balance in 2016 compared to 2012, except for the sectors: Wool, fabric and textiles, Leather and leather products, Metal and other primary products. The sectors of B\&H with surplus in foreign trade are: Wood and wood products, Clothing and the Other products sector. The largest deficit was recorded in the external trade of the Chemical products sector and Processed food and agricultural products, as well as Minerals, fuels and oils.

In addition to the absolute indicator, such as the foreign trade balance (i.e. net exports), a relative indicator was also analyzed - the relative foreign trade balance, which puts the absolute foreign trade balance in relation to the overall foreign trade exchange of that sector. The relative foreign trade balance, as one of the indicators of the current Trade Performance Index, shows whether the sector is the net exporter (where national production is higher than national consumption) or the net importer (where consumption is higher than production). The relative trade balance is the result of the ratio between the trade balance of the sector (exports minus imports) and 
total foreign trade of the sector (exports plus imports). The positive values of the indicators show that the sector is the net exporter, while the negative values show that the sector is the net importer.

Almost all sectors of Bosnia and Herzegovina are net importers, i.e. sectoral imports are higher than exports. The only sector that is the net exporter, besides the Other products sector, is the Wood and wood products $(20 \%)$. In addition to identificating sectors that are net importers, it can be noted which sectors had the most unfavorable position considering the foreign trade balance in relation to other sectors, namely: IT, telecommunication products and electronic equipment, and the sector of Wool, fabrics and textiles (-71\%) and Fresh food and raw agricultural products $(-54 \%)$.

In addition to the analysis of the share of sectoral export in national exports, the analysis of the share of sector export in the total world exports is also important for measuring the sectoral competitiveness. The world market share is obtained by putting the sector export of the selected country into the ratio with the world total exports (expressed in percentages). The greater share means that the significance of the observed country in the world export market is higher. This indicator, as the static indicator, shows an image in the particular year, but does not explain the source of any changes during the period.

Compared to other sectors in $\mathrm{B} \& \mathrm{H}$, Leather and Wood sectors had the largest share in the world market, while the least productive products on the world market were products of IT and consumer electronics, as well as transport equipment. Data on the participation of sectors in world exports confirms that traditional, laborintensive and raw material base and low level of technological intensity sectors dominate in the $\mathrm{B} \& \mathrm{H}$ sector's offer on the world market, compared to other capitalintensive sectors and sectors with the higher level of technological intensity.

In addition to the indicators that show the share of the sectorial export in the world market in a given year, it is important to determine whether the world market share is increasing or decreasing in the observed period. The indicator that shows the percentage change in the share of country exports in total world exports in the observed year (2016) in relation to the first year of the analyzed period (2012) is the indicator of the relative change in participation in the world market (see Table 5). The positive value of this indicator shows that the sector has increased its share in the world market.

All countries are striving for greater production and export activity diversification, as more diversified production and export structure reduces the country's vulnerability to price changes in the international markets. The significance of diversification is particularly evident during the last global economic crisis, when many developing countries, especially those heavily relying on exports of fuel and other goods that are priced on world commodity markets, faced the significant decline in export prices and deterioration in exchange relationship. The most 
successful sectors in terms of product and market diversification of exports are those who produce and sell the wide range of products, or the greater number of different products in different foreign markets.

Production diversification is the good indicator of the production structures and levels of economic development, and it limits the dependence on the small number of products, thereby reducing the country's vulnerability to the external sector-specific shocks.

The sectors with the highest production diversification of $\mathrm{B} \& \mathrm{H}$ are Processed food and agricultural products (three leading products had $28.4 \%$ share in total sector export), Clothing (whose three leading products account for $35.2 \%$ in total sector exports in 2016) and IT, telecommunication products and electronic devices.

Table 5: Production and market diversification of $B \& H$ sectoral exports in $2016^{7}$

\begin{tabular}{|l|c|c||}
\hline SECTOR & $\begin{array}{c}\text { Sector ranking by product } \\
\text { diversification in relation to } \\
\text { the total number of } \\
\text { countries ranked }\end{array}$ & $\begin{array}{c}\text { Sector ranking according } \\
\text { to market diversification } \\
\text { in relation to the total } \\
\text { number of countries } \\
\text { ranked }\end{array}$ \\
\hline Fresh food & $47(177)$ & $85(177)$ \\
\hline Processed food & $31(169)$ & $91(169)$ \\
\hline $\begin{array}{l}\text { Wood, wood products and } \\
\text { paper }\end{array}$ & $30(148)$ & $30(148)$ \\
\hline Textiles & $59(131)$ & $78(131)$ \\
\hline Chemicals & $63(157)$ & $51(157)$ \\
\hline $\begin{array}{l}\text { Leather and leather } \\
\text { products }\end{array}$ & $60(127)$ & $73(127)$ \\
\hline $\begin{array}{l}\text { Metals and other basic } \\
\text { manufactures }\end{array}$ & $58(152)$ & $31(152)$ \\
\hline Non-electronic machinery & $81(150)$ & $94(150)$ \\
\hline IT \& Consumer electronics & $18(121)$ & $50(121)$ \\
\hline Electronic components & $81(134)$ & $74(134)$ \\
\hline Transport equipment & $80(150)$ & $40(150)$ \\
\hline Clothing & $34(127)$ & $68(127)$ \\
\hline $\begin{array}{l}\text { Miscellaneous } \\
\text { manufacturing }\end{array}$ & $93(160)$ & $73(160)$ \\
\hline Minerals, fuels and oils & $17(165)$ & $76(165)$ \\
\hline
\end{tabular}

Source: International Trade Centre. (2019), retrieved from:

http://www.intracen.org/itc/market-info-tools/trade-statistics/, accessed: 10.02.2019.

\footnotetext{
${ }^{7}$ In order to demonstrate the level of market diversification better, instead of the index that measures market diversification, Table 5 shows the market diversification of exports of the B\&H sector through the rank of the sector according to the level of market diversification in relation to the total number of ranked countries for 2016.
} 
The worst situation regarding the product diversification of the exports is in the Transport equipment sector (ranked $80^{\text {th }}$ out of 150 ranked countries, and the three leading products participate in the total sectoral exports, about $65.5 \%$ ), Electronic Components $\left(81^{\text {st }}\right.$ from 134 countries) and Non-electronic machinery (ranked $81^{\text {st }}$ out of 150 ranked countries).

Based on the data of the leading products by sectors (see Appendix 1 for more details), it is noted that products with low level of finalization are prevailing in the production structure of exports, i.e. with low level of processing (e.g. in the sector Wood, wood products and paper the leading products are wood logs only processed by pilling). In the exports structure of the Leather and leather products sector, where the footwear belongs, as well as in the Clothing sector, the so-called lohn jobs are most represented, which involve the temporary import of products with the lower stage of processing, treatment or finishing, and re-export to the country of origin or to a third country. Almost $30 \%$ of total B\&H exports realised in 2016, or one third of $\mathrm{B} \& \mathrm{H}$ exports, according to statistical procedures, were categorized as exports after inward processing. This confirms that in the production structure of certain sectors products that are labor-intensive, low accumulative are present, where foreign partners use the benefits of cheap labor force and low environmental standards of Bosnia and Herzegovina.

The market diversification or diversification of partner countries reduces the country's dependence on the small number of export markets, and hence the vulnerability to shocks from those countries. Based on the data that is shown in Table 5, on the level of market diversification of B\&H exports in 2016, it is noted that the best market diversification of exports in 2016 was achieved in the sectors: Wood, wood products and paper ( $30^{\text {th }}$ out of 148 ranked countries), Metal and other primary products ( $31^{\text {st }}$ out of 152 ranked countries) and Transport vehicles ( $40^{\text {th }}$ out of 150 ranked countries). The three main export destinations for $\mathrm{B} \& \mathrm{H}$ sectoral export in 2016 (see Appendix 2 for more details) are the member countries of the European Union and the signatory countries of the CEFTA 2006 Agreement.

\subsection{Analysis of the current Trade Performance Index of Bosnia and Herzegovina's economic sectors}

The current index and change index in the world market share show the ranking of the sectors on the world market among countries that export the same product categories. The export competitiveness of the observed sector is better when its ranking, or the ordinal number on the scale, is lower. 


\section{Graph 3: Trade performance index of the economic sectors of Bosnia and Herzegovina}

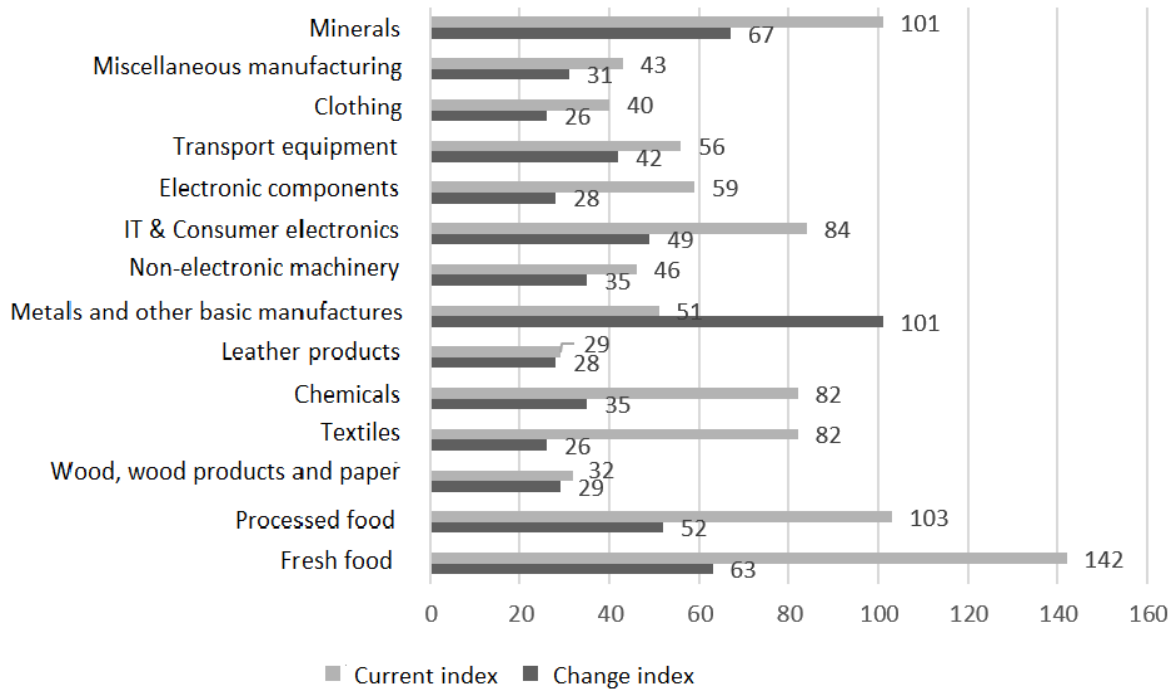

Source: ITC Trade Competitiveness Map. (2019), retrieved from: https://tradecompetitivenessmap.intracen.org/tpic.aspx, accessed: 10.02.2019. Author's grafical view.

The numbers next to the columns in Graph 3 correspond to the ranking of the sectors on the world market among countries that export the same product categories. The first pillar in Graph 3 indicates the ranking according to the current Trade performance index, i.e. the country's position for the observed sectors in the given year (2016) according to trade performance. Based on the current index, the best placed export sector of $\mathrm{B} \& \mathrm{H}$ (according to international competitiveness for 2016 ) is the Leather Products sector, which took $29^{\text {th }}$ position (followed by Wood and wood products sector ranked $32^{\text {th }}$ and Clothing ranked $40^{\text {th }}$ ), from the number of countries for which the Trade performance index is calculated by the ITC for the observed sector.

The second pillar in Graph 3 indicates the change of position during the analyzed period (from 2012 to 2016), and shows the improvement or deterioration of the trade performance of the B\&H sector. According to this indicator, the best results were recorded by Textile and Clothing Sector, which was ranked $28^{\text {th }}$, and Leather and Leather products $\left(28^{\text {th }}\right)$ and Wood and Wood Products $\left(29^{\text {th }}\right)$, among the countries for which the Trade Performance Index is calculated for the given sectors. 


\subsection{Sources of changes in competitiveness in the observed period}

The third group of indicators within the Trade Performance Index are indicators that explain the sources of changes in competitiveness in the observed period, i.e. in the period from 2012 to 2016, and they are divided into: the effect of competitiveness, initial geographical specialization, initial production specialization and adjustment effect. The sum of these four sources of change in competitiveness gives the relative change in the world market share.

The competitiveness effect means the change in the sector exports share in the destination country market multiplied by the initial participation of the partner country's imports in world trade. The positive value of this indicator indicates that the analyzed sector improves competitiveness due to the effect of competitiveness. The greater the percentage, greater the change in the competitiveness of the sector caused by the effect of competitiveness. The initial geographic specialization tells how much the certain geographical position affects the competitive advantage that the sector is achieving in trade with foreign trade partners. However, the initial production specialization shows in which sectors $\mathrm{B} \& \mathrm{H}$ has the production tradition. The adjustment effect of sector exports to the demand on the world market affects its foreign trade performance, that is, how much the sector is ready to quickly and fully adapt to the consumers demands in the world market.

Table 6 shows the sources of changes in the competitiveness of the three most competitive B\&H export sectors. The most competitive sectors, B\&H "winners" sectors, i.e. economic sectors which were the most competitive in 2016 according to the Trade Performance Index, are: Wood, wood products and paper, Leather and leather products and Clothing.

Table 6: Sources of changes in competitiveness for three most competitive sectors of Bosnia and Herzegovina

\begin{tabular}{||l|l|l|l|l|l||}
\hline \hline Sector & $\begin{array}{l}\text { Relative } \\
\text { change in } \\
\text { the world } \\
\text { market } \\
\text { share (\%) }\end{array}$ & $\begin{array}{l}\text { Effect of } \\
\text { competitiveness }\end{array}$ & $\begin{array}{l}\text { Initial } \\
\text { geographic } \\
\text { specialization }\end{array}$ & $\begin{array}{l}\text { Initial } \\
\text { production } \\
\text { specialization }\end{array}$ & $\begin{array}{l}\text { Adaptation } \\
\text { effect }\end{array}$ \\
\hline $\begin{array}{l}\text { Wood, wood } \\
\text { products and } \\
\text { paper }\end{array}$ & $3.22 \%$ & $2.5 \%$ & $0.07 \%$ & $1.48 \%$ & -0.84 \\
\hline $\begin{array}{l}\text { Leather and } \\
\text { leather } \\
\text { products }\end{array}$ & $0.55 \%$ & $4.9 \%$ & $-0.66 \%$ & $0.79 \%$ & -4.47 \\
\hline Clothing & $4.66 \%$ & $2.76 \%$ & $0.72 \%$ & $1.75 \%$ & -0.57 \\
\hline
\end{tabular}

Source: International Trade Centre. (2019), retrieved from:

http://www.intracen.org/itc/market-info-tools/trade-statistics/, accessed: 10.02.2019. 
The adjustment effect has contributed to the worsening of the export position of all three sectors observed, but due to other sources of change in competitiveness, the change in sectoral competitiveness has gone towards improving their position on the world market. The main source of change in competitiveness for all three most competitive sectors (Wood, wood products and paper, Clothing and Leather and leather products) lies in the effect of competitiveness, that is, in improving factors that affect the competitiveness.

\section{Conclusion}

The concept of competitiveness proved to be the new pillar in the economic development of each national economy. Competitiveness includes awareness of the limitations and challenges set by global competition, at the time when state action is limited by the available budget and rules of international organizations regulating international trade, primarily the World Trade Organization, and the private sector faces significant restrictions on improving competitiveness in the international market.

Although there is an agreement that the foreign trade deficit is one of the key economic problems of Bosnia and Herzegovina, not enough attention is paid to the structural problems of economy nor the structure of foreign trade. In this paper, the aim was to identify the sectors in which B\&H is competitive, in order to build macro international competitiveness based on those sectors and increase exports, and hence to improve the foreign trade balance and growth. Based on the Trade Performance Index analysis for 14 export sectors of Bosnia and Herzegovina, the identified "winners" export sectors are the following: Wood, wood products and paper, Leather and leather products and sector Clothes. The "losers" sectors in foreign trade are: Fresh food and raw agricultural products, Processed food and agricultural products and IT, telecommunication products and electronic devices.

Based on the presented research results, ancillary hypothesis was confirmed. The low level of international competitiveness is reflected in the poor sectoral structure of exports characterized by a large share of resource-intensive products, primarily in the Wood and Wood Products sector. The export sector structure of $\mathrm{B} \& \mathrm{H}$ is characterized by sectors with low-stage processing products, that is, lowvalue-added products, while technology-intensive products have been identified as "losers" (such as IT, telecommunications products and electronic devices). Bearing in mind the aforementioned, the initial main hypothesis of the research is accepted, i.e. the sectors of Bosnia and Herzegovina have low level of international trade competitiveness.

When creating the new strategies and policies for improving competitiveness, the creation of conditions for improving the competitiveness of export sectors, identified as "winners", should be the highest priority, since the competitiveness of 
the whole $\mathrm{B} \& \mathrm{H}$ economy is improving by further improving their competitiveness. However, numerous structural changes of the B\&H economy are also needed. The change in the economic structure should be directed towards bringing the most competitive sectors into larger stages of processing and accelerated development of technologically intensive and highly profitable sectors, so that they become significant exporters. Such export structure with the higher value added would significantly improve the $\mathrm{B} \& \mathrm{H}$ foreign trade balance and achieve multiple positive effects on the economy as a whole.

\section{References}

Agency for Statistics of Bosnia and Herzegovina. (2017). Foreign trade of B\&H. Thematic Bulletin.

Ajginger, K., Barenthaler-Sieber, S., Vogel, J. (2013). Competitiveness under New Perspectives. European Commission: Welfare Wealth Work, Brussels.

Bjelic, P. (2008). International trade. Belgrade: Publishing Center of the Faculty of Economics in Belgrade.

Cho, D. S. \& Moon, H. C. (2000). From Adam Smith to Michael Porter: Evolution of Competitiveness Theory. Singapore: World Scientific Publishing Co. Pte. Ltd.

Cvetanovic, S., Despotovic, D., \& Nedic, V. (2012). Comparative analysis of business sophistication of Serbia and its neighboring countries. Industry 40 (4).

European Commission. (2001). Competitiveness of European manufacturing. Brussels: DG Enterprise.

Flejterski S. (1984). Istota i mierzenie konkurencyjności międzynarodowej. Gospodarka Planowa 9. Warszawa.

International Trade Centre. (2019), preuzeto sa: http://www.intracen.org/itc/market-infotools/trade-statistics.

International Trade Centre. (2014). ITC by Country Report - Bosnia and Herzegovina.

International Trade Centre. (2014). Trade Competitiveness Map - Benchmarking national and sectoral trade performance - Trade Performance Index - Technical notes. ITC"s Market Analysis and Research.

Kitson, M. Martin, R. \& Tyler P. (2004). Regional Competitiveness: An Elusive yet Key Concept? Regional Studies Association. Vol. 38.9.

Kovacevic, M. (2010). The causes of the decline and very low level of competitiveness of Serbia. Proceedings of the conference "How to increase the competitiveness of Serbia's economy and exports. Belgrade: Faculty of Economics in Belgrade.

Krajisnik, M. (2014). Foreign Trade - Politics and Business. Banja Luka: Faculty of Economics in Banja Luka.

Krugman, P. (1990). The Age of Diminished Expectations. Cambridge:The MIT Press.

Krugman, P. (1996). Making Sense of the Competitiveness Debate. Oxford Review of Economic Policy 12(3).

OECD. (2001). OECD INTERNATIONAL TRADE AND COMPETITIVENESS INDICATORS (ITCI). http://www.oecd.org/economy/growth/1860588.pdf.

Porter, M. (1998). The Competitive Advantage of Nations: With a new introduction. New York: Free Press. 
Porter, M. E. (2004). Building the microeconomic foundations of prosperity: Findings from the business competitiveness index. World Economic Forum.

Schwab, K. \& Porter, M. (2008). Global competitiveness report 2008. World Economic Forum.

Tassey, G. (2001). R\&D and Long-Term Competitiveness: Manufacturing's Central Role in a Knowledge-Based Economy. Report, National Institute of Standards and Technology, Gaithersburg, MD: NIST.

Tesic, J. (2013). Openness and competitiveness of small transition economies. Banja Luka: ACTA ECONOMICA, No. 18.

Tomas, V. (2011). National competitiveness and expenditure on education, research and development. Journal of Competitiveness, Vol 2/2011. Zlin: Faculty of management and Economics.

Ulengin, F., Ulengin B. \& Onsel S. (2002). A power-based measurement approach to specify macroeconomic competitiveness of countries. Socio-Economic Planning Sciences, Vol 36.

Vukovic, D. (2013). Correlation analysis of regional competitiveness indicators: the case of the Republic of Serbia. Economic Horizons, Volume Xv, Volume 3. Kragujevac: Faculty of Economics, University of Kragujevac.

World Economic Forum. (2017). World Competitiveness Report.

\section{IZVOZNA KONKURENTNOST PRIVREDNIH SEKTORA BOSNE I HERCEGOVINE}

Rezime: Konkurentnost nacionalne ekonomije, njenih sektora i kompanija je od ključne važnosti za ekonomski rast i razvoj u uslovima globalnog tržišta. Ta važnost je posebno izražena za male otvorene ekonomije kakva je Bosna i Hercegovina (BiH). Bosna i Hercegovina mora da jača izvoznu poziciju na svojim najkonkurentnijim sektorima da bi mogla da se razvija u uslovima sve više liberalizovane svjetske trgovine, sa sve izraženijom konkurencijom. Cilj ovog rada je da se istraži sektorska stuktura izvoza BiH, konkurentnost, značaj i performance pojedinih sektora u izvozu BiH, kako bi se utvrdile slabosti i utvrdili mogući pravci poboljšanja. Za potrebe ove analize, za ocjenu konkurentnosti sektora korišćena je metoda Analize trgovinske konkurentnosti (engl. Trade Competitiveness Map), i to korišćenjem Indeksa spoljnotrgovinskih performansi (engl. Trade Performance Index, TPI). Osnovni cilj metodologije je utvrđivanje sektorskih izvoznih performansi, kako bi se olakšala strateška tržišna istraživanja i praćenje nacionalnih spoljnotrgovinskih performansi. BiH ima lošu izvoznu sektorsku strukturu sa niskim nivoom međunarodne konkurentnosti što se ogleda $u$ velikom učešću resursno-intenzivnih proizvoda i proizvoda niske faze obrade sa malom dodatom vrijednošću. Poboljšanje konkurentnosti se može postići sa jačanjem najkonkurentnijih sektora, kao i promjenom privredne strukture u pravcu razvoja tehnološko intenzivnih i visoko profitabilnih grana privrede.

Ključne riječi: konkurentnost, izvoz, indeks trgovinskih performansi, privredni sektori, Bosna i Hercegovina 


\section{APPENDIX 1}

Table: Share of three leading products in the Bosnia and Herzegovina's export sector

\begin{tabular}{|c|c|c|c|c|}
\hline \multirow[t]{2}{*}{ Sector } & \multirow{2}{*}{$\begin{array}{l}\text { Average sector } \\
\text { share in B\&H } \\
\text { exports } \\
\text { (in period 2012- } \\
\text { 2016) } \\
\end{array}$} & \multicolumn{2}{|c|}{$\begin{array}{c}\text { Share of three } \\
\text { leading products in } \\
\text { B\&H export } \\
\end{array}$} & \multirow[t]{2}{*}{$\begin{array}{l}\text { Leading export product of the } \\
\text { B\&H sector } \\
\text { (according the HS) }\end{array}$} \\
\hline & & 2012 & 2016 & \\
\hline $\begin{array}{l}\text { Metals and other } \\
\text { basic manufactures }\end{array}$ & $17.6 \%$ & $45.3 \%$ & $36.6 \%$ & $\begin{array}{lll}760120 & - & \text { Aluminium; } \\
\text { unwrought, alloys } & \\
\end{array}$ \\
\hline $\begin{array}{l}\text { Miscellaneous } \\
\text { manufacturing }\end{array}$ & $13.9 \%$ & $58.9 \%$ & $48.5 \%$ & 940190 - Seat; parts \\
\hline Minerals, fuel, oils & $13.2 \%$ & $39.9 \%$ & $56.8 \%$ & $271600-$ Electricity \\
\hline $\begin{array}{l}\text { Wood, wood } \\
\text { product and paper }\end{array}$ & $9.4 \%$ & $38.3 \%$ & $36.4 \%$ & $\begin{array}{l}440710-\text { Wood trimmed by } \\
\text { length, with milling or cutting }\end{array}$ \\
\hline $\begin{array}{l}\text { Leather and leather } \\
\text { product }\end{array}$ & $7.4 \%$ & $60.2 \%$ & $62.7 \%$ & $\begin{array}{l}640610-\text { Footwear; parts, } \\
\text { uppers and parts thereof, other } \\
\text { than stiffeners }\end{array}$ \\
\hline $\begin{array}{l}\text { Non-electronic } \\
\text { machinery }\end{array}$ & $7.1 \%$ & $36.8 \%$ & $33 \%$ & $\begin{array}{l}840999-\text { Engines; parts for } \\
\text { internal } \\
\text { engines }\end{array}$ \\
\hline Chemicals & $6.5 \%$ & $44.5 \%$ & $40.6 \%$ & 283620- Disodium carbonate \\
\hline Processed food & $6.1 \%$ & $35 \%$ & $28.4 \%$ & $\begin{array}{ll}151219 \quad-\text { Vegetable oils; } \\
\text { sunflower seed or safflower oil }\end{array}$ \\
\hline Clothing & $4.8 \%$ & $27.1 \%$ & $35.2 \%$ & $\begin{array}{l}961900 \text { - Sanitary towels (pads) } \\
\text { and tampons, napkins and napkin } \\
\text { liners for babies and similar } \\
\text { articles, of any material }\end{array}$ \\
\hline $\begin{array}{l}\text { Electronic } \\
\text { components }\end{array}$ & $3.2 \%$ & $49.8 \%$ & $59.7 \%$ & $\begin{array}{l}854449-\text { insulated electric } \\
\text { conductors }\end{array}$ \\
\hline $\begin{array}{l}\text { Transport } \\
\text { equipment }\end{array}$ & $3.1 \%$ & $68.2 \%$ & $65.5 \%$ & $\begin{array}{l}870899-\text { Vehicle parts and } \\
\text { accessories }\end{array}$ \\
\hline $\begin{array}{l}\text { Unclassified } \\
\text { production }\end{array}$ & $3 \%$ & $99.8 \%$ & $99.8 \%$ & 999999 \\
\hline Fresh food & $3 \%$ & $49.2 \%$ & $41.8 \%$ & $\begin{array}{l}410150 \text { - Hides and skins; raw, } \\
\text { whole, of bovine or equine } \\
\text { animals, }\end{array}$ \\
\hline Textiles & 1.2 & 49 & $48.7 \%$ & $\begin{array}{l}961900 \text { - Sanitary towels (pads) } \\
\text { and tampons, napkins and napkin } \\
\text { liners for babies and similar } \\
\text { articles, of any material }\end{array}$ \\
\hline $\begin{array}{l}\text { IT and Consumer } \\
\text { electronics }\end{array}$ & 0.1 & 39.9 & $37 \%$ & $851761-$ Base stations \\
\hline
\end{tabular}

Source: International Trade Centre. (2019), retrieved from:

http://www.intracen.org/itc/market-info-tools/trade-statistics, accessed: 10.02.2019. 


\section{APPENDIX 2}

Table: Share of the three main export destinations by sectors in 2016

\begin{tabular}{|c|c|c|}
\hline Sector & $\begin{array}{c}\text { Share of the three } \\
\text { main export } \\
\text { destinations in } 2016\end{array}$ & $\begin{array}{l}\text { Three main export destinations } \\
\text { in } 2016\end{array}$ \\
\hline Unclassified production & $98.1 \%$ & Germany, Slovenia, Serbia \\
\hline Textiles & $81.2 \%$ & Italy, Germany, Austria \\
\hline Clothing & $77.9 \%$ & Germany, Italy, Austria \\
\hline Leather and leather products & $72.8 \%$ & Italy, Germany, Austria \\
\hline Electronic components & $70.3 \%$ & Slovenia, Austria, Serbia \\
\hline Non-electronic machinery & $69.5 \%$ & Slovenia, Germany, Italy \\
\hline Minerals, fuel, oils & $59.5 \%$ & Serbia, Croatia, Montenegro \\
\hline IT and Consumer electronics & $58.5 \%$ & Slovenia, Croatia, Austria \\
\hline Miscellaneous manufacturing & $58.3 \%$ & Germany, Croatia, Austria \\
\hline Processed food & $57.4 \%$ & Croatia, Serbia, Italy \\
\hline Fresh food & $49.2 \%$ & Austria, Italy, Croatia \\
\hline Chemicals & $47.3 \%$ & Italy, Serbia, Croatia \\
\hline $\begin{array}{l}\text { Metals and other basic } \\
\text { manufactures }\end{array}$ & $45.1 \%$ & Croatia, Serbia, Italy \\
\hline $\begin{array}{l}\text { Wood, wood product and } \\
\text { paper }\end{array}$ & $43.2 \%$ & Serbia, Croatia, Italy \\
\hline Transport equipment & $54.0 \%$ & $\begin{array}{l}\text { Germany, Luxembourg, } \\
\text { Slovenia }\end{array}$ \\
\hline
\end{tabular}

Source: Internatioanal Trade Centre. (2019), retrieved from:

http://www.intracen.org/itc/market-info-tools/trade-statistics, accessed: 10.02.2019.

\section{Authors' biographies}

Milenko Krajišnik, $\mathrm{PhD}$, an associate professor, is employed at the Faculty of Economics, University of Banja Luka, Department of International Economic Relations. Entrusted disciplines in undergraduate study: Foreign trade business and Economics and development of national economy. Trusted disciplines in graduate studies: Theory and Policy of International Trade and the Integration and Regionalization of the World Economy. Trusted discipline in doctoral studies: International economy. He is the author of the number of scientific papers in the fields of international economics, economic development and public finance. He is currently the President of the Fiscal Council of the Republic of Srpska.

Sanja Popović is graduate economist and she is currently student of master study at the Faculty of Economics, University of Banja Luka. She worked at the Central Bank of Bosnia and Herzegovina and is currently employed in UniCredit Bank a.d. Banja Luka in the Financial Management Division. Her fields of interest are international economics, public finances and monetary economics. Sanja is the author of several original scientific papers in the field of European integration. 